\title{
Innovation of Interactive Multimedia Based on Guided Inquiry Using Articulate Storyline 3 as A Learning Media for Carbon and Silicone Materials in Non-Metal Inorganic Chemistry Courses
}

Inovasi Multimedia Interaktif Berbasis Inkuiri Terbimbing Menggunakan Articulate Storyline 3 Sebagai Media Pembelajaran Materi Karbon dan Silikon pada Mata Kuliah Kimia Anorganik Non Logam

\begin{tabular}{l}
\hline Author \\
\hline Sri Nur Afrida \\
Universitas Negeri Medan \\
Medan, Indonesia \\
snurafrida@gmail.com \\
Retno Dwi Suyanti \\
Universitas Negeri Medan \\
Medan, Indonesia \\
retno_suyanti@yahoo.com \\
Ajat Sudrajat \\
Universitas Negeri Medan \\
Medan, Indonesia
\end{tabular}

\section{Duconomics}

\section{Sci-meet}

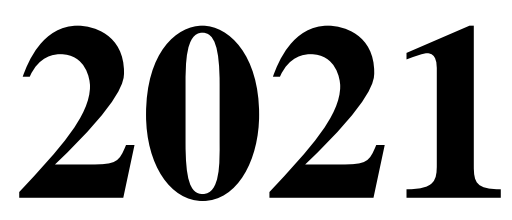

VOLUME 1

JULI

Page

192-199

DOI

10.37010/duconomics.v1.5441

Corresponding Author

Sri Nur Afrida

snurafrida@gmail.com

082219984457

$\begin{array}{r}\text { Abstract } \\ \hline \text { This study aims to develop interactive multimedia based on } \\ \text { guided inquiry on carbon and silicon materials for non-metal } \\ \text { inorganic chemistry courses using Articulate Storyline } 3 \\ \text { software based on BSNP. This research is a development } \\ \text { research (R\&D) with the ADDIE model. The sample in this } \\ \text { study were lecturers at the State University of Medan, Faculty } \\ \text { of Mathematics and Natural Sciences majoring in Chemistry } \\ \text { as many as } 3 \text { people as validators of media and material } \\ \text { experts that were tailored to the needs. The research } \\ \text { instrument was in the form of a BSNP questionnaire filled out } \\ \text { by material expert validators and media expert validators. } \\ \text { Data were analyzed descriptively qualitatively. The results } \\ \text { showed that guided inquiry-based interactive multimedia on } \\ \text { carbon and silicon materials with an average score of } 3.67 \\ \text { and included in the "very feasible" criteria for use on carbon } \\ \text { and silicon materials in non-metal inorganic chemistry } \\ \text { learning.. } \\ \hline \text { Keywords }\end{array}$

Penelitian ini bertujuan untuk mengembangkan multimedia interaktif berbasis inkuiri terbimbing pada materi karbon dan silikon mata kuliah kimia anorganik non-logam menggunakan software Articulate Storyline 3 berdasarkan BSNP. Penelitian ini merupakan penelitian pengembangan $(R \& D)$ dengan model ADDIE. Sampel dalam penelitian ini yaitu dosen Universitas

Negeri Medan Fakultas Matematika dan Ilmu pengetahuan Alam jurusan Kimia sebanyak 3 orang sebagai validator ahli media dan materi disesuaikan dengan kebutuhan. Instrumen penelitian berupa angket BSNP yang diisi oleh validator ahli materi dan validator ahli media. Data dianalisis secara deskriptif kualitatif. Hasil penelitian menunjukkan bahwa multimedia interaktif berbasis inkuiri terbimbing pada materi karbon dan silikon dengan skor rata-rata 3,67 dan termasuk dalam kriteria "sangat layak" digunakan pada materi karbon dan silikon pada pembelajaran kimia anorganik non-logam. 


\section{PENDAHULUAN}

Kemajuan teknologi informasi dan komunikasi berkembang begitu pesat dan memberikan dampak yang begitu besar di bidang pendidikan dimana sekolah maupun perguruan tinggi diharapkan mengikuti perkembangan yang terjadi. Perkembangan teknologi komputer kemudian menjadi salah satu peluang dalam mengembangkan media yang tepat dan sesuai dengan kebutuhan mahasiswa pada proses pembelajaran (Mashami \& Khaeruman, 2020).

Pembelajaran kimia umumnya mengandung banyak konsep-konsep yang bersifat abstrak sehingga untuk memahaminya dibutuhkan daya imajinasi dengan bantuan gambargambar visual yang dapat mendukung proses pembelajaran. Keberhasilan belajar tidak hanya ditentukan oleh dosen dan mahasiswa saja, tetapi juga ada pengaruh dari suatu media pembelajaran yang digunakan serta bahan-bahan pembelajaran yang digunakan saat proses pembelajaran sedang berlangsung (Prasetyo et al., 2014). Media pembelajaran memegang peranan penting dalam proses pembelajaran (Zuhri \& Rizaleni, 2016). Adanya media pembelajaran agar mahasiswa dapat memahami pokok bahasan dalam waktu yang lebih singkat dan menyenangkan (Sittichailapa et al., 2015).

Salah satu mata kuliah wajib dalam struktur kurikulum prodi pendidikan kimia di Universitas Negeru Medan (UNIMED) adalah mata kuliah kimia anorganik non logam yang berbobot 3 SKS. Dimana mata kuliah ini membahas mengenai unsur-sunsur non logam seperti misalnya karbon, hydrogen, boron dan lainnya. Berdasarkan hasil observasi dan wawancara yang dilakukan oleh salah satu dosen kimia anorganik non logam di Universitas Negeri Medan diperoleh informasi bahwa proses pembelajaran pada mata kuliah kimia anorganik non logam pada tahun ajaran 2020/2021 masih dalam proses pembelajaran daring (dalam jaringan).

Pemanfaatan multimedia khususnya pada pembelajaran kimia anorganik nonlogam di program studi pendidikan kimia pada proses pembelajaran daring sangat diperlukan untuk menunjang proses pembelajaran yang dilakukan dengan konsep yang menarik dan didukung dengan animasi, video, gambar dan suara. Salah satu upaya yang dilakukan agar mengefektifkan multimedia yaitu dengan cara mengkombinasikannya model pembelajaran berupa model pembelajaran inkuiri terbimbing (Herdini et al., 2018). Dalam proses pembelajaran, mahasiswa tidak hanya berperan sebagai penerima pelajaran melalui penjelasan dosen secara verbal, tetapi mereka menemukan sendiri inti dari materi ajar itu sendiri sehingga seluruh aktivitas yang dilakukan mahasiswa diarahkan untuk mencari dan menemukan jawaban sendiri. Kolaborasi antara ilmu pengetahuan dan teknologi yang dikemas menjadi media pembelajaran berupa multimedia yang di integrasikan dengan model pembelajaran inkuiri terbimbing memberikan kontribusi terhadap kurikulum yang berwawasan global (Nugraheni et al., 2019).

Multimedia interaktif yang dikembangkan menggunakan program Articulate Storyline 3 dimana program ini dapat mendukung fitur seperti flash dalam pembuatan animasi namun memiliki interface semudah power point sehingga menjadikan program Articulate Storyline 3 ini dapat dimanfaatkan untuk membantu pembuatan multimedia interaktif (Yasin, 2017).

\section{METODE}

Jenis penelitian yang digunakan adalah penelitian pengembangan (research and development) yang dimodifikasi dari pengembangan model ADDIE (Analysis, Design, Development, Implementation, and Evaluation). Model ADDIE merupakan konsep pengembangan produk. Konsep ADDIE yang diterapkan di sini adalah membangun pembelajaran berbasis kinerja. Pembelajaran yang berpusat pada siswa, inovatif, otentik, dan 
inspirasional (Branch, 2010). Model ADDIE ini menggunakan 5 tahap atau langkah pengembangan yaitu (1) tahap analisis, (2) tahap desain. (3) tahap pengembangan, (4) tahap implementasi dan (5) tahap evaluasi. Dari kelima tahapan ADDIE hanya 3 langkah yang diadaptasikan dalam penelitian yaitu sampai uji kelayakan pada tahap pengemabangan. Secara singkat tahapan penelitian pengembangan multimedia interaktif berbasis inkuiri terbimbing dapat dilihat pada Gambar 1.

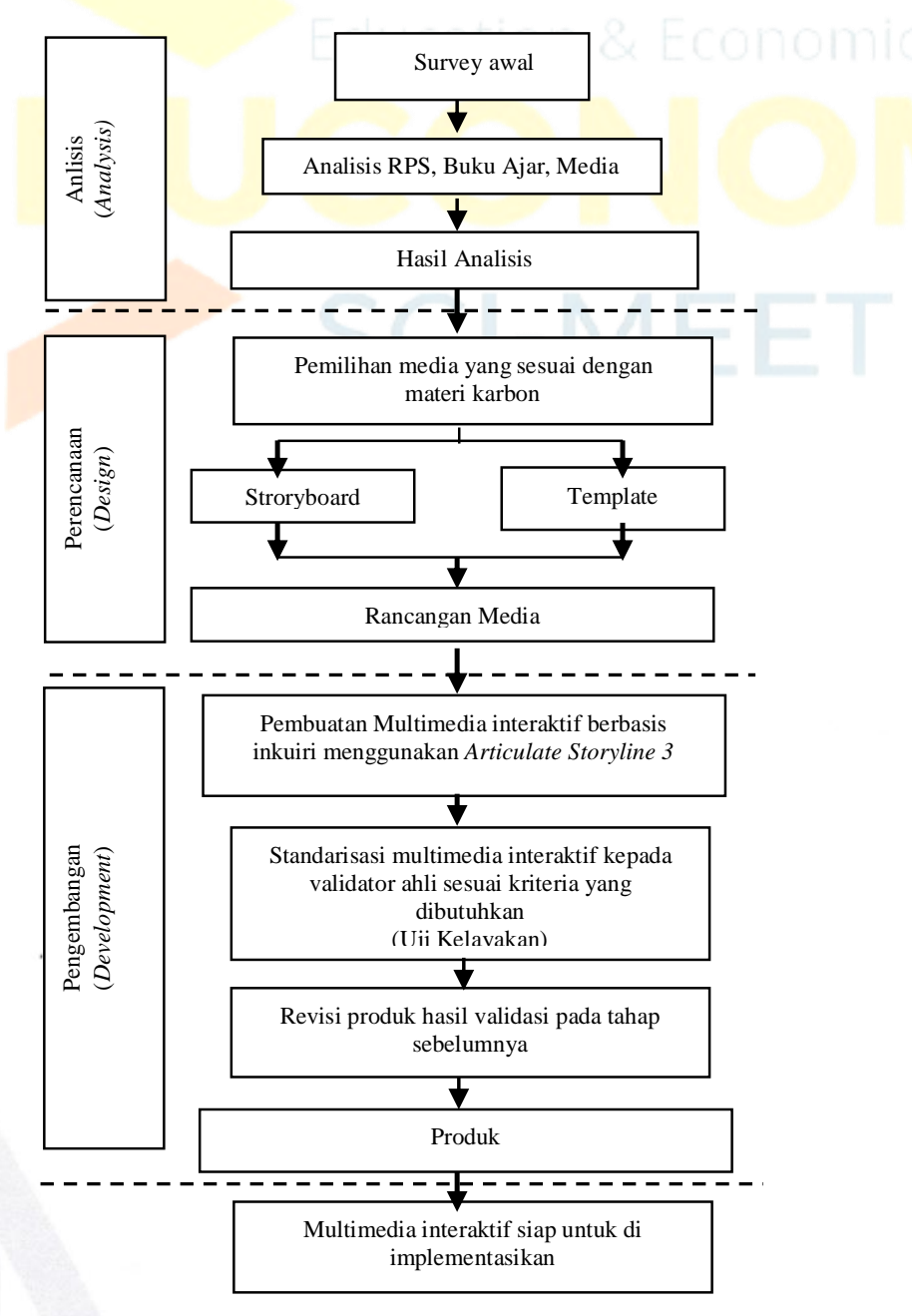

Gambar 1. Bagan Alur Pengembangan Multimedia Interaktif

Sampel dalam penelitian ini yaitu dosen Universitas Negeri Medan Fakultas Matematika dan Ilmu pengetahuan Alam jurusan Kimia sebanyak 3 orang sebagai validator ahli media dan materi disesuaikan dengan kebutuhan. Data dianalisis secara deskriptif kualitatif menggunakan instrumen nontes yaitu lembar angket validasi BSNP termodifikasi dengan tes skala likert menggunakan kategori pilihan genap. Angket diberikan kepada validator ahli pada bidangnya berjumlah tiga orang yaitu dua validator ahli materi dan satu validator ahli media. Kemudian angket diisi dengan menggunakan skala likert 1-4 dimana jawaban yang diberikan sangat setuju sampai sangat tidak setuju.

Penelitian kelayakan dialakukan melalui dua tahap. Tahap I dikatakan lolos jika semua butir dalam instrument penilaian mendapat "nilai" atau respon positif. Jika terdapat butir yang dijawab negatif, maka multimedia interaktif berbasisi inkuiri terbimbing tersebut dinyatakan tidak lolos, sedangkan penilaian tahap II dianalisis dengan menghitung rerata skornya.

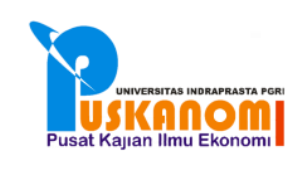


Tabel 1. Kriteria Validitas Analisis Nilai Rata-Rata

\begin{tabular}{ll}
\hline Rata-rata & Kriteria Validitas \\
\hline $3,26-4,00$ & Valid dan tidak perlu revisi (sangat layak) \\
$2,51-3,25$ & Cukup valid dan tidak perlu revisi (Cukup layak) \\
$1,76-2,50$ & Kurang valid, sebagian isi modul direvisi (kurang layak) \\
$1,00-1,75$ & Tidak valid dan perlu revisi total (tidak layak) \\
\hline
\end{tabular}

\section{HASIL DAN PEMBAHASAN}

Penelitian ini terdiri dari lima tahapan pengembangan ADDIE yang di adaptasi menjadi 3 tahaapan yaitu tahap analisis, tahap desain, tahap pengembangan, sampai dengan uji kelayakan.

1. Tahap Analisis

Pada tahap analisis ini menganalisis kebutuhan dengan melakukan analisis kurikulum Kerangka Kualifikasi Nasional Indonesia (KKNI) di jurusan prodi pendidikan Kimia FMIPA UNIMED, yang dilihat ialah capaian pembelajaran matakuliah dan sub capaian pembelajaran matakuliah Kimia Anorganik Nonlogam materi karbon dan silikon. Dalam kurikulum tersebut tercantum capaian pembelajaran matakuliah dan sub capaian pembelajaran matakuliah kimia anorganik nonlogam untuk materi karbon dan silikon, yang dapat dilihat pada Tabel. 1.

Tabel 2. Analisis Kebutuhan

\begin{tabular}{|c|c|}
\hline Analisis Kebutuhan & Hasil Analisis \\
\hline $\begin{array}{l}\text { Capaian Pembelajaran } \\
\text { Matakuliah (CPMK) }\end{array}$ & $\begin{array}{l}\text { Mampu mengidentifikasi struktur dan kereaktifan unsur- } \\
\text { unsur non logam serta manfaatnya dalam bidang industri } \\
\text { dan kehidupan sehari-hari. }\end{array}$ \\
\hline $\begin{array}{l}\text { Sub Capaian } \\
\text { Pembelajaran } \\
\text { Matakuliah } \quad \text { (Sub } \\
\text { CPMK) }\end{array}$ & $\begin{array}{l}\text { Mampu mendeskripsikan dan menganalisis tentang } \\
\text { keberadaan, karakteristik Karbon, Silikon dan } \\
\text { Senyawanya serta manfaatnya dalam bidang industri dan } \\
\text { kehidupan sehari- hari serta melalui penyelesaian }\end{array}$ \\
\hline $\begin{array}{l}\text { Indikator dalam } \\
\text { pengembangan media } \\
\text { pembelajaran }\end{array}$ & $\begin{array}{l}\text { 1) Menjelaskan keberadaan dan kelimpahan unsur } \\
\text { Karbon dan Silikon serta senyawanya di alam. } \\
\text { 2) Menjelaskan kecenderungan unsur Karbon dan } \\
\text { Silikon dalam golongannnya. } \\
\text { 3) Menuliskan reaksi- reaksi yang terjadi pada Karbon } \\
\text { dan Silikon } \\
\text { 4) Mengkarakterisasi dan identifikasi unsur Karbon dan } \\
\text { Silikon serta senyawanya } \\
\text { 5) Menjelaskan aplikasi unsur karbon dan Silikon serta } \\
\text { senyawanya dalam bidang industri dan kehidupan } \\
\text { sehari-hari }\end{array}$ \\
\hline
\end{tabular}

Selanjutnya analisis bahan ajar dan analisis media pembelajaran dilakukan dengan wawancara kepada dosen matakuliah kimia anorganik nonlogam dari hasil wawancara dihasilkan bahwa buku ajar yang digunakan oleh mahasiswa tidak terdapat buku khusus yang menjadi pegangan mahasiswa dan media pembelajaran yang digunakan berupa media powerpoint. Dari hasil analisis yang dilakukan, selanjutnya data yang diperoleh digunakan untuk menentukan kebutuhan media pembelajaran yang akan dikembangkan.

2. Tahap Desain 
Merdeka Belajar dan Tantangan Ekonomi dalam Menyongsong Era Society 5.0

Pada tahap ini dilakukan dengan membuat flowchart dan storyboard. Pembuatan flowchart bertujuan agar multimedia yang dikembangkan memiliki alur navigasi yang terkonsep. Dan pembuatan storyboard bertujuan untuk membuat frame yang sesuai dan juga menarik. Adapun hasil produk dari pengembangan multimedia interaktif berbasis inkuiri terbimbing pada materi karbon dan silikon dapat dilihat pada Gambar 2, Gambar 3, Gambar 4, Gambar 5 dan Gambar 6.
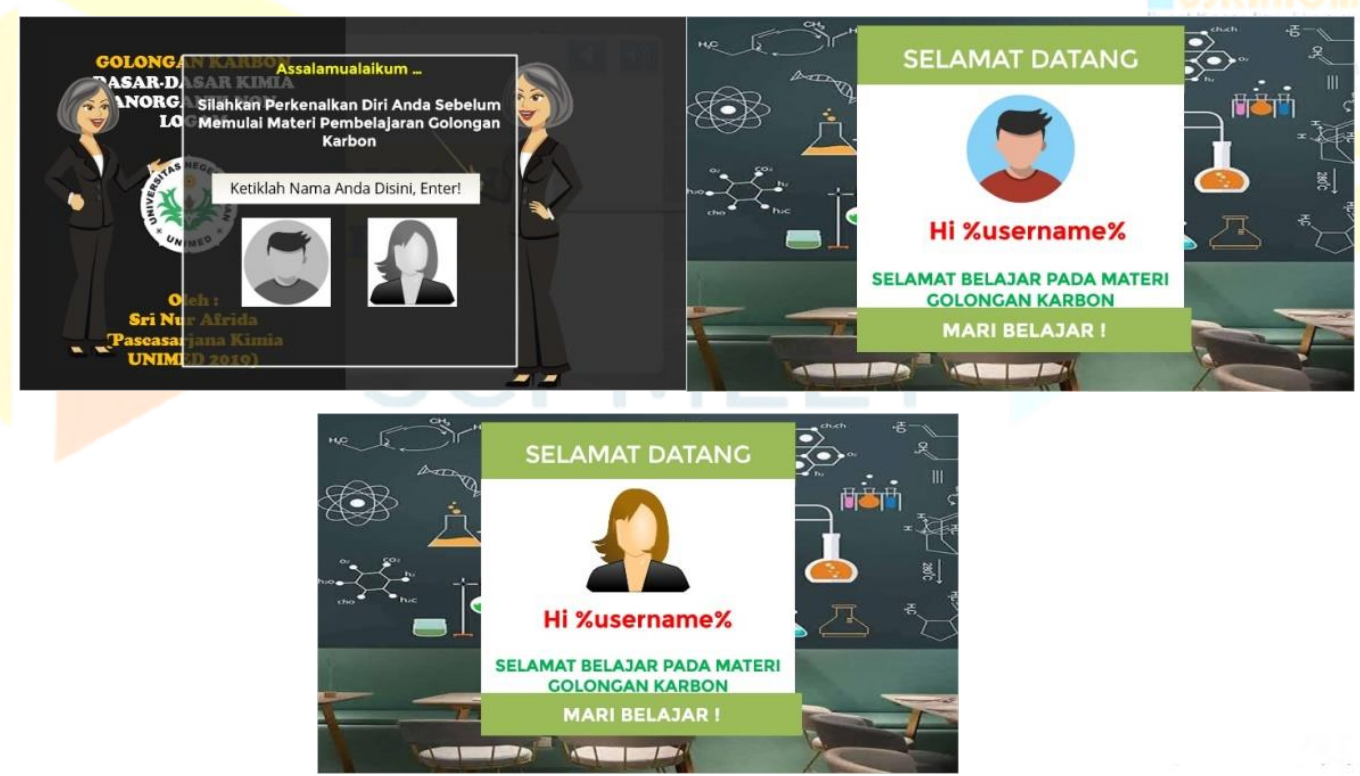

Gambar 2. Tampilan intro media
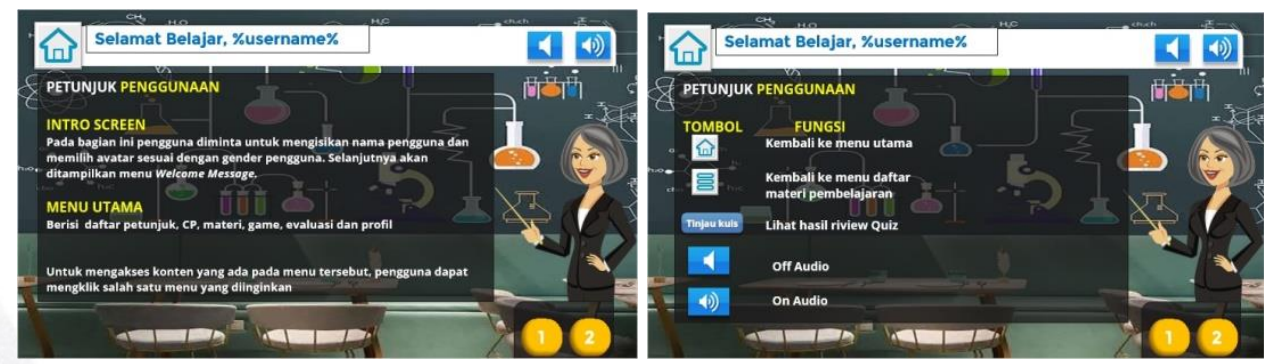

Gambar 3. Tampilan petunjuk penggunaan

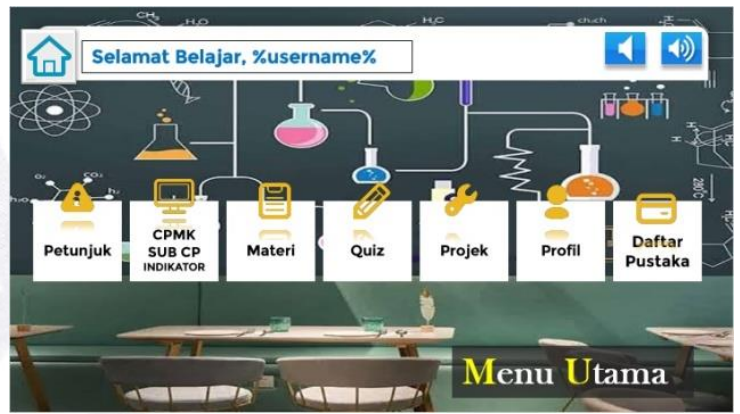

Gambar 4. Tampilan Menu 
Duconomics Sci-meet Vol. 1

Juli, 2021
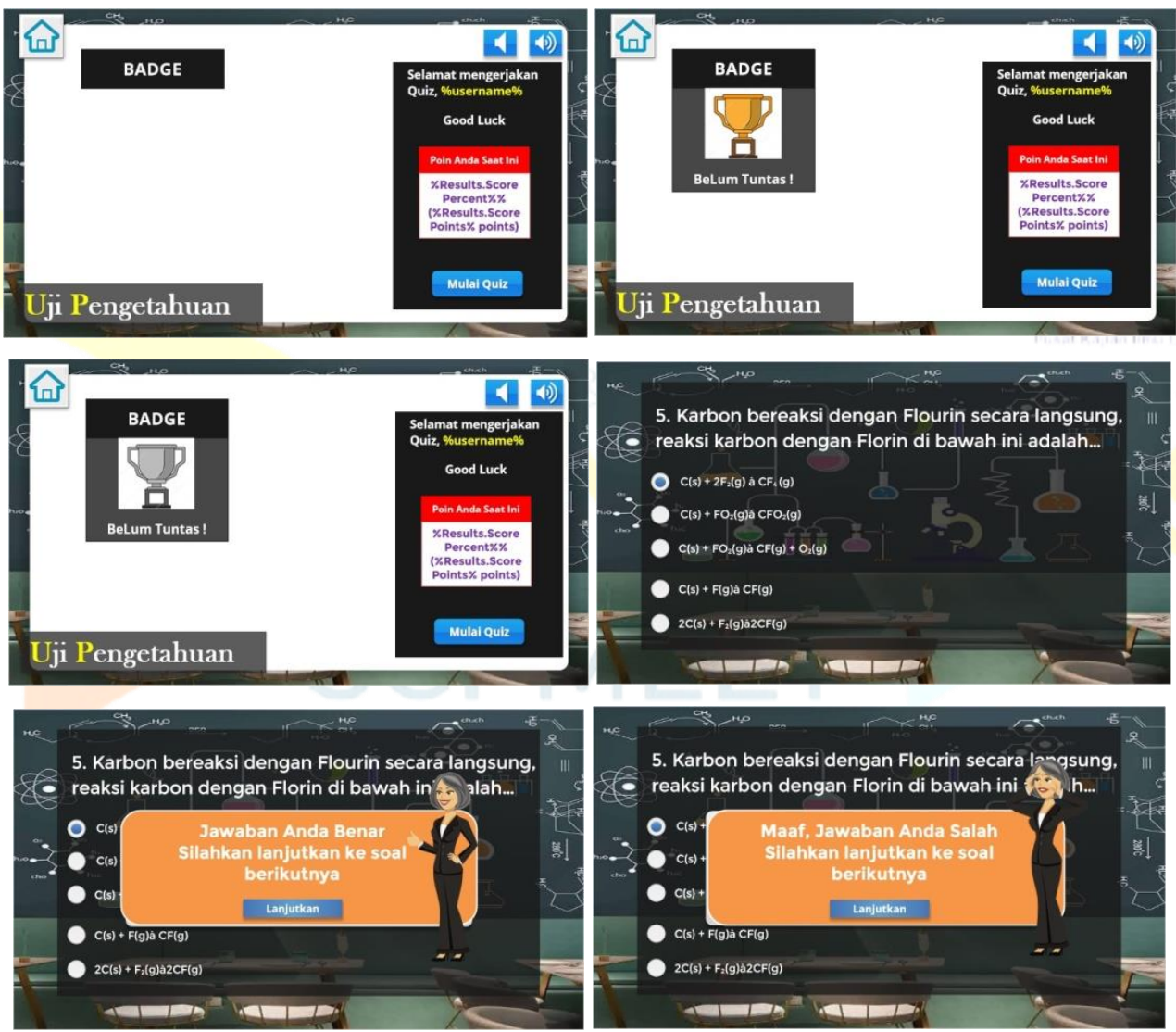

Gambar 5. Tampilan quiz.

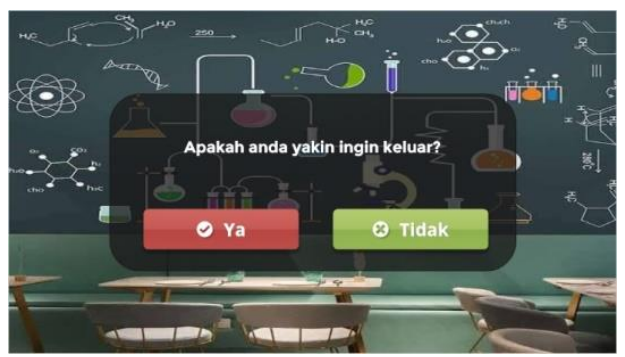

Gambar 6. Tampilan exit

\section{Tahap Pengembangan}

Pada tahap ini dilakukan dengan pembuatan multimedia interaktif berbasis inkuiri terbimbing yang dikembangkan (produk) dengan menggunakan software articulate storyline 3 pada materi karbon dan silikon.

Kemudian multimedia interaktif yang telah dikembangkan selanjutnya dilakukan standarisasi multimedia interaktif kepada validator ahli sesuai kriteria yang dibutuhkan menggunakan angket BSNP termodifikasi. Tingkat kelayakan multimedia nteraktif yang dikembangkan pada materi karbon dan silikon berdasarkan BSNP yang telah dimodifikasi meliputi kelayakan isi, kelayakan bahasa dan kelayakan penyajian dikemukakan pada Gambar 7. 


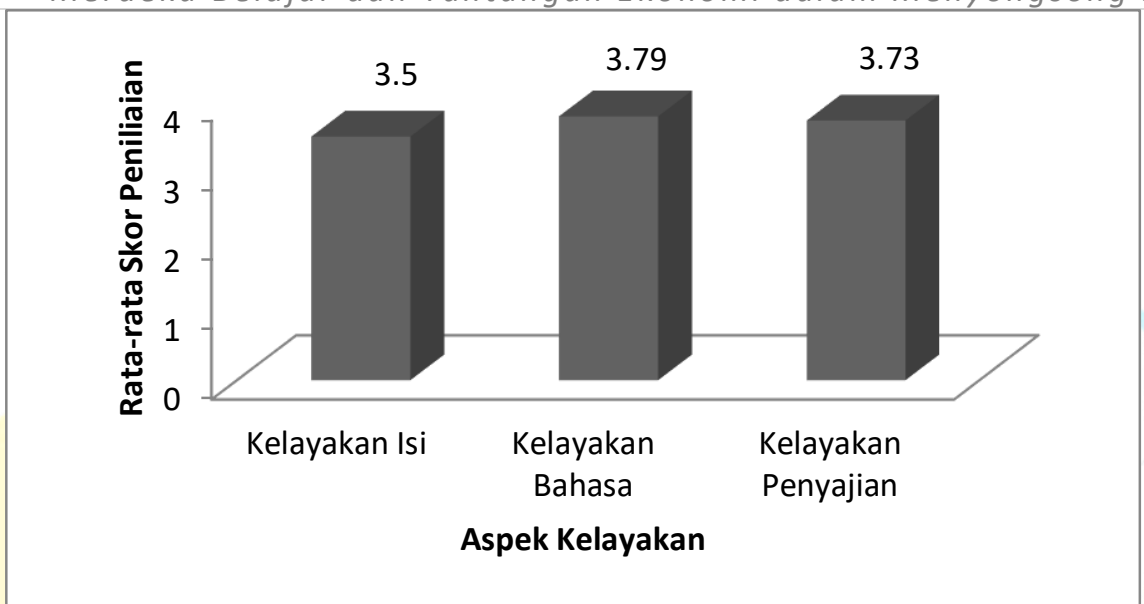

Gambar 7. Grafik Hasil Analisis Kelayakan Penyajian Multimedia Interaktif Berbasis Inkuiri Terbimbing

Pada grafik hasil analisis kelayakan multimedia interaktif yang dikembangkan diperoleh bahwa rata - rata kelayakan isi 3,35 artinya media sangat layak dan tidak perlu direvisi, kelayakan bahasa 3,79 artinya media sangat layak dan tidak perlu direvisi, dan kelayakan penyajian 3,73 artinya media sangat layak dan tidak perlu direvisi. Sesuai dengan standar yang telah ditetapkan oleh BSNP, maka dapat disimpulkan bahwa multimedia interaktif pada materi karbon dan silikon matakuliah kimia anorganik nonlogam dengan skor rata-rata nilai kelayakan adalah 3,67 memiliki kriteria sangat layak untuk digunakan dalam pembelajaran. Adapun saran dan perbaikan yang didapat dari validator ahli diantaranya 1) Animasi sebaiknya tidak terlalu cepat, 2) Judul materi lebih terlihat jelas, 3) Penggunaan simbol kimia seperti simbol reaksi sebaiknya di sesuaikan, 4) Materi yang di tampilkan sebaiknya lebih di optimalkan dengan membuat peta konsep, 5) Penyesuaian judul pada lembar kerja siswa (LKM).

Multimedia interaktif berbasis inkuiri terbimbing yang dikembangkan setelah dilakukan validasi media oleh validator ahli dinyatakan valid dan dapat digunakan sebagai media pendukung pembelajaran kimia anorganik nonlogam di perguruan tinggi. Pengoperasian multimedia yang sangat mudah mendukung penggunaan multimedia interaktif. Pengoperasian media pembelajaran berupa multimedia (media komputer) dapat menjadi alternative dalam pembelajaran karena kelebihahnya yang dapat dilakukan dengan mengintegrasikan animasi, audio, dan suara (Pekdag 2010).

\section{PENUTUP}

Berdasarkan hasil dan pembahasan, maka dapat disimpulkan bahwa multimedia interaktif berbasis inkuiri terbimbing dengan bantuan software articulate storyline 3 pada materi karbon dan silikon pada pembelajaran kimia anorganik nonlogam layak digunakan sebagai media pembelajaran berdasarkan penilaian oleh validator ahli dengan instrument BSNP (Badan Standar Nasional Pendidikan). Hasil uji kelayakan dari validator ahli dengan skor ratarata nilai kelayakan adalah 3,67 memiliki kriteria sangat layak untuk digunakan dalam pembelajran.

\section{DAFTAR PUSTAKA}

Branch, R. M. (2010). Instructional design: The ADDIE approach. In Instructional Design: The ADDIE Approach. Springer US. https://doi.org/10.1007/978-0-387-09506-6

Herdini, H., Linda, R., Abdullah, A., Shafiani, N., Darmizah, F. 'Alaina, \& Dishadewi, P. (2018). Development of interactive multimedia based on Lectora Inspire in chemistry subject in junior high school or madrasah tsanawiyah. JOURNAL OF EDUCATIONAL 
SCIENCES, 2(1). https://doi.org/10.31258/jes.2.1.p.46-55

Mashami, R. A., \& Khaeruman, K. (2020). Pengembangan Multimedia Interaktif Kimia Berbasis PBL (Problem Based Learning) untuk Meningkatkan Keterampilan Generik Sains Siswa. Hydrogen: Jurnal Kependidikan Kimia, 8(2). https://doi.org/10.33394/hjkk.v8i2.3138

Nugraheni, W., Mulyani, S., \& Ashadi, A. (2019). PENGEMBANGAN MULTIMEDIA INTERAKTIF KIMIA BERBASIS INKUIRI TERBIMBING UNTUK PEMBELAJARAN MATERI POKOK HIDROKARBON DAN MINYAK BUMI KELAS XI MIA. INKUIRI: Jurnal Pendidikan IPA, $=8(2)$. https://doi.org/10.20961/inkuiri.v8i2.37756

Prasetyo, Y. D., Ikhsan, J., Lis, R., \& Sari, P. (2014). Ce-15 the Development of Android-Based Mobile Learning Media As Chemistry Learning for Senior High School on Acid Base , Buffer Solution, and Salt Hydrolysis. Proceeding of International Conference On Research, Implementation And Education Of Mathematics And Sciences 2014, Yogyakarta State University, May, 18-20.

Sittichailapa, T., Rattanachai, R., \& Polvieng, P. (2015). The Development of Model Learning Media of Sorting Algorithm. Procedia - Social and Behavioral Sciences, 197. https://doi.org/10.1016/j.sbspro.2015.07.333

YASIN, A. (2017). KELAYAKAN TEORITIS MULTIMEDIA INTERAKTIF BERBASIS ARTICULATE STORYLINE MATERI SISTEM REPRODUKSI MANUSIA KELAS XI SMA. BioEdu, 6(2).

Zuhri, M. S., \& Rizaleni, E. A. (2016). Pengembangan Media Lectora Inspire dengan Pendekatan Kontekstual pada Siswa SMA Kelas X. Pythgoras, 5(2), 113-119. 